\title{
AC 2008-2392: CHALLENGES FOR INTERNATIONAL STUDENTS IN A GLOBALLY CHANGING ENVIRONMENT
}

Soumya Keshavamurthy, Mississippi State University

Anurag Srivastava, Mississippi State University

Adrienne Minerick, Mississippi State University

Noel Schulz, Mississippi State University 


\title{
Challenges for International Students in a Globally Changing Environment
}

\begin{abstract}
Indian and Chinese students have comprised the largest section of the population for graduate research and degree programs in North America and other developed countries for more than two decades. Recently, India and China have become the fastest growing nations in technology, science and engineering. For the American university system, recruiting international students will be more competitive in the coming years due to technical opportunities and financial benefits easily achieved in their home countries. Universities and the United States technical community will need to proactively meet the demand for engineers in North America.

International student recruitment has suffered since the global security crisis, which began in 2001 after the September 11 terrorist attack. The tightening of immigration policies and visa issuance in the USA has drastically influenced the number of graduate students studying in engineering schools across the United States. In addition, a series of challenges faced by international students during the journey from the beginning of graduate study to graduation are making student life more stressful than is necessary. Due to newly introduced policy issues, rules and regulations, students are finding their time usurped by government bureaucracy and are thus less focused on research goals and academic study. It is important for faculty mentors to be well informed of potential challenges in advance; this will enable them to help new international students navigate the system and achieve their goals. In this paper, a team of an international graduate student and faculty seek to develop resources for potential faculty mentors and graduate students at institutions within North America. The goal will be to a) make faculty and students aware of some common challenges and $b$ ) provide guidance on dealing with these challenges from both a faculty and a student perspective.
\end{abstract}

\section{Introduction}

There are many advantages of pursuing advanced degrees at U.S. universities. Some of them are achieving leadership in many scientific disciplines, top caliber academics with international exposure, high national spending on research and development, talented colleagues, hundreds of schools, freedom of thought, conscience and expression, competitive egalitarian society, high standards of living, and generous stipends.

For students coming from India or China, these advantages may not be enough. Funding, limitations on employment after graduation, expensive tuition and also visa regulations are some of the concerns faced by international students. Due to various rules and regulations encountered by students combined with India and China becoming the fastest growing nations, high caliber competitive students are decreasing in spite of an increase in students coming to the U.S. to pursue advanced degrees. The number of international students studying at U.S. universities has grown significantly during the past 50 years, from 49,000 students in 1950s to about 583,000 students in $2007^{1}$. After September 11th, the growth rate of recruiting international students was reduced by approximately $1 \%$ in 2002 and due to more stringent security measures implemented by the U.S. government a 2.4\% decline in international students in U.S. universities in 2003 was 
noticed $^{1}$. Since then the growth rate has been sluggish with $3.9 \%$ in 2007 which was the same in $2001^{1}$ after the terrorist attack. This is a very important concern noted by MSNBC with headlines that describe this decline in recruiting foreign students ${ }^{2}$. Some of the reasons are described by Krupnick $^{3}$ which are:

- Ample job opportunities for students in home countries.

- More universities offering esteemed advanced degrees in the student's home countries.

- Stringent visa rules after the September $11^{\text {th }}$ attack.

In addition to the above-described reasons, financial inconvenience for an international student to study in a U.S. university makes it less appealing to travel abroad. To date, personal and family funds have been the primary source of funding for many international students ${ }^{4}$. In terms of fields of study, business and management has been in the top with engineering being the second option ${ }^{5}$. As a result of these new rules and regulations and less awareness among faculty and staff at universities, international students are facing more challenges a) at the beginning of graduate study, b) at graduation and also c) after graduation. As a result, the engineering student recruitment rate is declining ${ }^{1}$. Kramer et.al ${ }^{6}$ (2007) demonstrated a method to increase graduate enrollment and attract top students to graduate study by introducing concurrent BS/MS programs. Some of the challenges faced by a student will be elaborated upon in the next sections of this paper, with some possible solutions proposed by the authors.

\section{Problems and possible solutions}

\section{Admission process}

The most important part of applying for admission to an advanced degree program in the United States is to pull together all the documents required to be sent to the university. Some of the essential documents are copies of the passport, test scores such as GRE (Graduate Record Examination) for Engineering or GMAT (Graduate Management Admission Test) for business schools, TOEFL (Test of English as a Foreign Language), TSE (Test of Spoken English) (requirement in some universities), copies of transcripts of undergraduate degree along with degree certificate, recommendation letters, and financial documents along with the application fee. After sending all these documents to the admissions department, students have to follow up with the staff at the admissions office for the status of the application. At some universities, the staff members at the admissions office are not very prompt in responding to student queries. Often, universities have a web-based system for the students to check application status or assess further documents that may be required in the process. Unfortunately, many websites are updated infrequently and the time-to-decision can be lengthy. Consequently, the student might miss providing required documents for an assistantship if the admission staff does not promptly notify the student. To attract the best students to a university, it is important that this system be as efficient and effective as possible.

After the student is admitted, some universities require financial documentation showing funds for a minimum of one year of study at that university. This is required even if the student has been awarded an assistantship or scholarship. Universities may be unable to recruit academically strong students who are unable to provide sufficient financial documentation. For students coming from India and China, the requirement for financial documentation dissuades some 
students because they can get similar education back in their home country with the rapidly increasing infrastructure in India and China.

Once admitted to a U.S. university, the student has to apply for a student visa (F-1/ J-1). A visa allows a foreign citizen to travel to a U.S. port-of-entry and request permission from the U.S. immigration officer to enter the United States. It does not guarantee entry into the U.S. In 1952, the student nonimmigrant $\mathrm{F}$ and $\mathrm{J}$ visa categories were established. The $\mathrm{F}-1$ visa category is the most common student visa type for undergraduate and graduate students. The $\mathrm{J}-1$ visa category is for graduate or exchange students, teachers, scholars, and researchers who come to the United States under educational exchange programs.

In order to apply for a visa at a U.S. embassy or consulate, a SEVIS generated document (either an I-20 or DS-2019) issued by a U.S. college or university is required ${ }^{7}$. A SEVIS (Student and Exchange Visitor Information System) generated document (I-20) is issued by a U.S. college or university after proof for sufficient funds is established by the student. SEVIS, administered by the Bureau of Immigration and Customs Enforcement (ICE) within the Department of Homeland Security (DHS), is an Internet-based system that maintains data on foreign students and exchange visitors before and during their stay in the United States ${ }^{8}$. SEVIS was implemented after $9 / 11$ to expedite the tracking system that was incorporated in the Illegal Immigration and Immigrant Responsibility Act (IIRIRA) law by the President in $1996^{9}$. This SEVIS document is required to be submitted when applying for a student visa. The U.S. academic institution or program sponsor will provide the appropriate SEVIS generated form only when the student has been academically admitted to the institution. The student is required to pay a SEVIS fee which was implemented in July $2004^{9}$. There are many instances where the admission staff dealing with international admissions at a school has limited knowledge about this process. This is an area where many schools can streamline applications by educating staff and faculty with all the formalities to be completed when applying for a visa. At this point, the student is well prepared to go for a visa interview with all the necessary documents to any U.S. consulate or embassy in the country of residence. Prior appointments have to be made with the U.S. consulate by paying a nominal fee. The U.S. Department of State, Educational Information and Resources Branch booklet titled If You Want to Study in the United States lists steps necessary to apply for a student visa $^{10}$.

Graduate Study and Pre-Graduation

When a student has obtained an F-1 visa and is in the U.S. for academic study, an I-94 card will be issued at the port-of-entry along with SEVIS I-20 stamped with the date of entry. At the portof-entry, the student is again interviewed by an official and if the student's intentions for coming to United States as a non-immigrant are deemed insufficient, the student may not be granted access to enter the United States. The student can be deported back to their country of origin.

Many students often feel homesick if they are far away from family, but for an international student it is even more difficult because they cannot visit family frequently and may be struggling with the new culture. If they have to travel home under normal or emergency circumstances they need approval from international student services / center. International student services are functional bodies in most of the universities that assist students with all 
required visa rules and regulations. Unfortunately, many students have absolutely no knowledge about this procedure. Universities can prevent such problems by sending out regular communications to students on procedural issues such as this one. Faculty/staff should also be informed so that they can advise students accordingly by reminding them of the rules whenever students have to leave country for some purpose.

The system of education in the United States is very different compared to other countries like India or China. For example, credit hour system, grading system, minimum numbers of courses and course levels are all different. The student has to acclimate to these new methodologies including requirements such as how many registered courses qualify for full-time status. Every school has a minimum of 9 or 12 credit hours to be in full-time status and this varies if the student is a research assistant or teaching assistant. There are different levels of courses a student is expected to complete for an advanced degree. Many students get to know about all this when they arrive at their university. It is important for students to read any necessary published guidelines in their program of study. Most universities have orientation workshops at the beginning of every semester for new students and can cover some of these basics during orientation to get them familiarized with rules and regulations.

A vast majority of the student population pursuing advanced degrees are not provided with enough financial assistance to support expensive tuition and living in the United States. Some universities support students by giving scholarships, on-campus jobs, teaching and research assistants. Unfortunately, a majority of these opportunities are often catered to U.S. citizens rather than international students. If the student is not able to support tuition and living expenses, they can be distracted from their research and completing their degree. Possible solutions have to be worked out by universities and federal government to bring in more financial resources to recruit international students.

Students should also consider applying for on campus or off campus jobs. On campus jobs are mainly located in various university departments and facilities, where a student can work up to $20 \mathrm{hr} /$ week $^{11}$. Off campus jobs can include Internships or Curricular Practical Training (CPT or Co-Op). CPT is defined by Immigration and Naturalization Service (INS) as "employment which is an integral part of an established curriculum, including alternative work/study, internship, cooperative education, or any other type of required internship or practicum, which is offered by sponsoring employers through cooperative agreements with the school". CPT can be started after 9 months of starting an advanced degree at a particular school ${ }^{11}$. Students cannot work more than $40 \mathrm{hr} /$ week and can work full-time for 2 semesters (including summer term) or part time for any number of semesters. This option should not be considered by any student who is supported on a research assistantship. This is because a research assistantship is linked to a funded research project with set dates for deliverables. The student is hired to complete the research to meet these deliverables and interruptions for internships or co-ops which do not directly contribute to these goals can be grounds for removal of the research assistantship altogether. Any student interested in pursuing these opportunities should discuss them with their advisor; in some cases, it may be possible to work out a mutually beneficial research assistantship and internship appointment, while still meeting the deadlines for research deliverables. Hiring summer research interns in place of regular research assistants could be one solution. Every school has a career development center and the officials from these centers may not be up-to-date with rules and 
regulations for non U.S. citizens. After the September $11^{\text {th }}$ terrorist attack, these rules have been changed frequently with paperwork fees becoming more expensive.

Apart from all the above problems faced due to imposed rules and regulations, students also face difficulty in understanding the language due to regional accents, even after taking exams like TSE and TOEFL. The student here should be open and seek out the instructor to let them know about any problems incurred during the class. Further, many institutions offer English as a Second Language (ESL) discussion or support groups. Some universities conduct teaching workshops for teaching assistants but faculty should also encourage the students who have difficulty in understanding to attend these workshops.

When a student approaches graduation, planning is necessary to coordinate their graduate date with the start date of applying for an $\mathrm{H}-1 \mathrm{~B}$ visa ${ }^{12}$, which is explained in the next section. If a student plans to work in the United States after graduating and does not intend to work for a nonprofit company, then H1-B visa with an annual cap is important. The student has to apply for an Employment Authorization Card (EAD) via Optional Practical Training ${ }^{13}$ (OPT) before filing for a H-1B visa. The best time to graduate is currently summer as the student will remain on F-1 or $\mathrm{J}-1$ status until the $\mathrm{H}-1 \mathrm{~B}$ visa start date (October $1^{\text {st }}$ ). After graduation, a F-1 visa is no longer valid. Faculty can help the student in planning and aiming for summer graduation.

Post Graduation

The next step is finding employment which has a new set of visa regulations. After graduation, a $\mathrm{F}-1$ visa is no longer valid and a student has to obtain a new status of visa called $\mathrm{H}-1 \mathrm{~B}$ visa ${ }^{12}$. There is a grace period called Optional Practical Training ${ }^{13}$ (OPT) of about 12 months $+/-60$ days for finding employment and applying for the H-1B visa, if one decides to work in the U.S. after graduation. The fee for applying for OPT keeps rising every year and many students find this financially difficult because they are jobless and no longer in school during this period. This is one area where the government could facilitate the retention of talented, educated international students by not increasing the fee for OPT. One has to apply for OPT well in advance, usually 34 months before graduation. There are only four consulates in the U.S. that handle OPT cases. The U.S. government could also improve this process by increasing the number of consulates and simultaneously working to process such cases in a timely manner. During this grace period, an Employment Authorization Card (EAD) is issued with a start and an end date wherein an individual can start working for any employer. The international student services / center at different schools offers help in applying and verifying the documentation required for an EAD card. The student should apply for this in advance because if they fall out of visa status, they become questionable when applying for $\mathrm{H}-1 \mathrm{~B}$ visa and severe action can be taken against the student by the U.S. Immigration and Naturalization Services. Some schools offer mandatory workshops for the international graduating students but others keep it optional. Mandatory workshops by the school ensure that students are well aware of the situation. International organizations should also try to educate faculty by conducting some workshops at the beginning of the semester on some important guidelines and dates so that they can guide the student well in advance. Graduating students should follow up with the international student services / center usually one semester before they graduate so that they are well aware of all the regulations and do not face the problem of being out of status. 
After finding employment, the student should file for an $\mathrm{H}-1 \mathrm{~B}$ visa with their employer. There is an annual cap on H-1B admissions of 65,000 workers per fiscal year and 20,000 for workers who have advance degree from U.S. universities. An annual cap is not applicable if a student works for a non-profitable organization like a school, hospital or a rehabilitation center. The annual cap set by Congress was 115,000 in 1999 and 2000, 107,500 in 2001, and went back to 65,000 in $2002^{14}$. This shows a steady decline in the visas which impacts employment prospects of the new graduates. The filing for the petitions starts on April $1^{\text {st }}$, for the start date for employment being October $1^{\text {st }}$ of the respective fiscal year. These numbers get exhausted very quickly (April-2-07 for 65,000 cap and April-30-07 for 20,000 cap) ${ }^{15}$. The student has to be persistent by reminding their new employer about the cap exhaustion and also follow up with the numbers from USCIS newsletters. Basically the student has to find the employment by March for timely processing of $\mathrm{H}-1 \mathrm{~B}$ visas and to avoid being out of status. If the student is not on an OPT or F-1 visa status during the period of April (petition filing start date) to October (H-1B visa start date) of that fiscal year, working for that employer is termed to be illegal and the student might get deported back to their country of origin.

Many employers are not well aware of $\mathrm{H}-1 \mathrm{~B}$ visa regulations and thus hesitate to offer an international student a job in the company. This has been a big concern to the employers especially after September 11 due to more involved H-1B policies, which increases the amount of paperwork processed for the prospective candidate. Again students should proactively inform employers about these regulations during their interview; thus the student must strive to be well educated about all the visa policies required by the employer for processing an employee's (student in this case) H-1B visa on time. For the student to be fluent with these rules and regulations, universities and government can make an attempt to educate the students with various policies by conducting workshops every year for the graduating students. There is an advantage for universities to do this because they will retain their graduates in the U.S. and thus increase their reputation nationally.

\section{Summary}

The image of the United States as the best land of opportunity for pursuing graduate education has changed after the September $11^{\text {th }}$ terrorist attacks. International students have various opportunities to study and work in their home country, and thus the opportunity exists for U.S. rules and regulations to be improved in order to recruit graduate students. This is essential for the United States to maintain its diverse pool of graduate students.

International student recruitment has been declining since September $11^{\text {th }}$ attack. Some of the possible reasons for this decline are frequently changing rules and regulations, lack of awareness among universities, students, and faculty mentors, lack of responsibility among students, and scarcity of financial resources. Faculty mentors and universities have an opportunity to generate innovative ideas to recruit more international students and government should consider simplifying rules and regulations to streamline applications as described in this paper. The government and universities can improve this process by striving to educate mentors about important policies to relieve some of the problems international students are facing. Students also 
need to be more responsible and aware of all the regulations through International organizations of the universities and other available resources.

\section{Bibliography}

1. "International student enrollment and U.S. higher education enrollment trends, selected years 1950/602006/07", Open doors, Institute of International education, 2007

2. Hussain, Sakina S., "Schools struggle to combat foreign student drop", Aug 8, 2006, http://www.msnbc.msn.com/id/14034413/ (accessed in Jan 2008).

3. Krupnick, Matt, "Drop in Foreign Enrollment worries U.S. Educators," Contra Costa Times Jan 5. 2006.

4. "International students by primary source of funding, 2005/06 and 2006/07", Open doors, Institute of International Education, 2007

5. "International students by field of study, 2005/06 and 2006/07", Open doors, Institute of International Education, 2007

6. Kramer, B.; Easton, T.; "Concurrent B.S/M.S programs: A method to increase graduate enrollments and attract top students to graduate study", ASEE, 2007

7. "Proof of acceptance form I-20" http://www.ice.gov/sevis/becoming_nonimmigrant_student_52007.htm\#_Toc129683777 (accessed in Jan 2008)

8. "Student and exchange visitor system", http://www.ice.gov/sevis/index.htm (accessed in Jan 2008)

9. "Legislative history of SEVIS and general provisions of SEVIS rule", http://www.ice.gov/sevis/i901/faq1.htm (accessed in Jan 2008)

10. Morteza Sadat-Hossieny, "Challenges facing global engineering education considering current U.S. policies", ASEE, 2007

11. "F-1 student employment- on campus and off campus jobs", http://www.ice.gov/sevis/employment/index.htm (accessed in Jan 2008)

12. "Facts about H-1B visas", http://www.uscis.gov/portal/site/uscis/menuitem.5af9bb95919f35e66f614176543f6d1a/?vgnextoid=c487d92e80 03f010VgnVCM1000000ecd190aRCRD\&vgnextchannel=2411c9ee2f82b010VgnVCM10000045f3d6a1RCRD (accessed in Jan 2008)

13. "Optional Practical Training", http://www.ice.gov/sevis/students/opt.htm (accessed in Jan 2008)

14. "Washington wire, ASEE Prism Magazine" http://www.prismmagazine.org/january/html/january briefings.html (accessed in Jan 2008)

15. "Current Cap count for non-immigrant worker visas for Fiscal Year 2008" http://www.uscis.gov/portal/site/uscis/menuitem.5af9bb95919f35e66f614176543f6d1a/?vgnextoid=138b6138f8 98d010VgnVCM10000048f3d6a1RCRD\&vgnextchannel=91919c7755cb9010VgnVCM10000045f3d6a1RCR $\underline{\mathrm{D}}$ (accessed in Jan 2008) 